\title{
SENYAPAN DAN KILIR LIDAH DALAM ACARA GELAR WICARA MATA NAJWA 2020 SEBAGAI KAJIAN PSIKOLINGUISTIK
}

\author{
Ali Manshur, Fina Zaidatul I \\ IAI Darussalam Blokagung Banyuwangi \\ alimanshur@iaida.ac.id \\ devina1709@gmail.com
}

\begin{abstract}
Abstrak
Berbicara merupakan salah satu diantara empat kemahiran berbahasa. Kemahiran berbicara selalu dibutuhkan dalam kegiatan interaksi manusia khususnya berkomunikasi. Namun, manusia dalam berbicara mengalami sering mengalami kekeliruan dalam praktiknya, salah satunya adalah Senyapan dan Kilir Lidah yang ada di ada acara gelar wicara Mata Najwa 2020. Atas dasar itulah peneliti ingin menggali, mencari penyebab dan proses terjadinya Senyapan dan Kilir Lidah dari beberapa narasumber dalam acara tersebut. Senyapan dan Kilir Lidah merupakan salah satu kendala yang terjadi dalam kegiatan berkomunikasi baik resmi maupaun non resmi. Jenis penelitian ini bersifat kualitatif deskriptif dengan penelitian yang dilaksanakan untuk mengetahui masalah tersebut tanpa membandingkan atau menghubungkan antara masalah yang ada dengan gambaran interversi dari penelitian terhadap suatu fenomena. Dalam penelitian ini peneliti menggunakan teknik pengumpulan data dengan metode simak yang terdiri simak libat cakap, simak bebas lipat cakap, catat, dan rekam. Dengan menggunakan analisis Graunded Theory dengan metode pengkodean berporos (Axial Coding) model Paradigma. Berdasarkan analisis yang diperoleh dari hasi dari penelitian bahwa Senyapan dan Kilir Lidah dalam acara gelar wicara Mata Najwa 2020 terdapat banyak sekali senyapan yang dilakukan dengan berbagai faktor-faktor yang memengaruhinya.
\end{abstract}

Kata Kunci:Senyapan, Kilir Lidah, Gelar Wicara, Mata Najwa

\begin{abstract}
Speaking is one of the four language skills. Speaking skills are always needed in human interaction activities, especially communicating. However, humans in speaking experience often experience mistakes in practice, one of which is the Silent and Tongue Shrink at the Mata Najwa 2020 talk show. On that basis the researcher wants to explore, look for the causes and processes of the occurrence of Silence and Tongue Flashes from several sources in the event. Tongue smiles and flashes are one of the obstacles that occur in communicating activities, both official and nonofficial. This type of research is descriptive qualitative with research carried out to determine the problem without comparing or linking the existing problems
\end{abstract}


with the interversion picture of research on a phenomenon. In this study, researchers used a data collection technique with a listening method consisting of listening proficiently, listening freely fold proficiently, taking notes, and recording. By using Graunded Theory analysis with the Axial Coding method Paradigm model. Based on the analysis obtained from the results of the research that the Silence and the Flickering of the Tongue in the 2020 Mata Najwa talk show, there are lots of silences performed with various factors that influence it. Keywords: Smile, Tongue Flash, Speech Degree, Najwa's Eye

\section{A. Pendahuluan}

Manusia dalam berbicara yang ideal terbentuk dalam wujud ujaran yang lancar sampai ujaran tersebut selesai. Namun, ujaran tersebut tidak bisa ditetapkan dalam keadaan atau tempat tertentu. Sering kali saat berbicara mengalami gangguangangguan yang menghambat dalam berbicara. Hambatan tersebut dapat terealisasi dalam wujud interupsi diam, pengucapan bunyi, kata ataupun kalimat yang tidak merupakan bagian dari pesan. Gangguan tersebut dinamakan senyapan dan kilir lidah. Senyapan merupakan ketidaklancaran dalam berbicara yang disebabkan keraguan. Menurut Darjowidjojo (2015: 142) beranggapan senyapan lebih umum terjadi pada orang yang ragu-ragu. Sedangkan kilir lidah adalah kekhilafan penutur terhadap mitra tutur dalam kehidupan sosial. Sependapat dengan Jauhar (2015: 246) kilir lidah merupakan salah satu fenomena dalam produksi ujaran di mana pembicara terkilir lidahnya saat berbicara sehigga kata yang sudah diproduksi bukanlah kata yang dimaksudkan.

Senyapan dan kilir lidah seringkali terjadi pada manusia yang sedang berbicara dengan faktor karena saat berbicara lupa dengan kata-kata yang diucapkan atau sedang mencari kata-kata yang paling tepat. Gangguan tersebut mengakibatkan dalam memproduksi kalimat pada manusia. Dardjowidjojo (2014: 142) mengungkapkan tidak semua manusia dapat berbicara lancar dalam sebuah topik pembicaraan. Tanpa adanya persiapan menjadi pemicu terjadinya gangguan senyapan maupun kilir lidah. Tentunya ada strategi kesiapan-kesiapan dalam mengurangi senyapan dan kilir lidah yang terjadi saat berbicara yang aka dibahas secara mendalam.

Secara umum, senyapan terjadi hanya selang waktu beberapa detik saja. Yang dominan dipengaruhi oleh perasaan ragu-ragu ataupun hanya kebutuhan untuk 
bernapas sebentar. Namun berbeda konteks jika ujaran yang sudah terlebih dahulu dihafalkan dan sudah terkonsep sebelumnya. Kebanyaakan manusia melakukan senyapan selama berbicara karena beberapa hal. Pertama, seseorang yang melakukan senyapan sudah terlanjur memulai berbicara tetapi belum siap secara keseluruhan mengenai kata yang akan diproduksi. Kedua, manusia melakukan senyapan dikarenakan lupa dengan apa kata apa yang akan diujarkan. Sehingga, manusia harus mengingat kata apa yang diujarkan. Ketiga, manusia lebih baik dalam memilih kata, diksi yang berkaitan dengan makna kata yang akan diujarkan.

Pemilihan kata tersebut agar meminimalisasi kata yang tidak cocok untuk diujarkan kepada mitra tutur. Namun menurut Dardjowidjojo (2015: 144) ketidaksiapan dan kewaspadaan saat penutur melakukan berbicara terwujud dalam dua macam senyapan: (1) senyapan diam dan (2) senyapan terisi. Pada senyapan diam manusia dalam berbicara berhenti sejenak dan hanya diam. Selanjutnya, menemukan kata yang akan diujarkan manusia melanjutkan ujaran yang sebelumnya terhenti. Sedangkan senyapan berisi ialah senyapan yang dilakukan penutur melalui proses meretrif kata secara tidak cepat. Sehingga diisi dengan senyapan tersebut dengan kata sebagai pengganti. Padanan bahasa yang digunakan yakni kata seperti apa, itu, anu, siapa itu sering dipakai sebagai pengisi saat senyapan terjadi.

Senyapan atau keraguan dalam berbicara tidaklah terjadi di pelbagai tempat. Akan tetapi kepastian tempatnya belum dapat diketahui oleh para praktisi yang menelitinya. Menurut Boomer 1965: 148-158 dalam (Dardjowidjojo 2014: 146) banyaknya penelitian yang berpendapat berbeda tempat letak senyapan, ada yang mengatakan terjadi sesudah kata pertama dalam suatu klausa atau kalimat. Namun, secara demikian dapat dilihat di tempat-tempat sesuai dengan kesepakan ahli (Clark \& Clark 1977: 267), yakni: a. Jeda pada gramatikal

b. Batas konstituen yang lainnya

c. Sebelum kata pertama dalam konstituen

Dalam gangguan berbicara berupa kilir lidah mempunyai dua macam jenis. Yakni pertama kilir lidah yang disebabkan karena adanya seleksi kata yang keliru. Yang kedua kilir lidah yang disebakan oleh asembling. a.

Kekeliruan Seleksi 
Kilir lidah yang di sedangkan seleksi yang keliru terbagi menjadi tiga.

Diantaranya:

1) Seleksi semantik

2) Malaproprisme

3) Campur kata(blends)

Gangguan seleksi semantik yang keliru biasa dikenal dengan istilah "Freudian slips" meretrif kata yang tidak diinginkan. Kekeliruan tersebut bukan karena sifatnya yang disengaja. Istilah malaproprisme berasal dari sebuah karangan novel yang bernama Ny. Malaprop. Dalam kisah novel tersebut Ny. Malaprop digambarkan sebagai wanita yang berkelas tinggi dengan memakai kata-kata yang berlebihan. Namun dalam konteks pemakaiannya banyak kekeliruan meskipun sedikit ada kemiripan. Dan kilir lidah tersebut dapat terjadi pada sapa saja. Contoh dalam lawakan banyak sekali pemain-pemain dalam berbicara melakukan kilir lidah yang disengaja. Seperti kata "antisipasi” diganti dengan "antisisapi".

Model yang terakhir kilir lidah disebabkan dengan adanya campur kata (blends) yang terjadi disebabkan manusia sedang dalam keadaan tergesa-gesa sehingga mengambil suku kata atau sebagian suku dari kata pertama atau sebagian kata tersebut.

\section{B. Landasan Teori 1. Teori Penelitian}

Ilmu Psikolinguistik merupakan ilmu Hibrida, yakni kajian ilmu bahasa yang menggabungkan antara psikologi dengan linguistik. Menurut Ahmadi (2015: 1) ilmu Psikologi merupakan ilmu pengetahuan mengenai perilaku manusia yang terlihat maupun tidak terlihat. Sedangkan Linguistik merupakan ilmu yang mengkaji tentang bahasa secara alamiah. Dengan begitu ilmu Psikolinguistik merupakan ilmu mengenai hubungan antara bahasa dan akal manusia. Hal tersebut sependapat dengan Ahmadi (2015: 3) Psikolinguistik merupakan ilmu tentang perilaku berbahasa, baik secara terlihat ataupun tidak terlihat. Selain ilmu Psikolinguistik, muncul keberadaan ilmu baru sebagai perkembangan ilmu Psikolingistik. Ilmu tersebut gabungan dari ilmu Neurolinguistik dengan Psikolinguistik yang dikaji dalam satu permasalahan. Chaer berpendapat dalam buku Neuropsikolinguistik (2018: 2) bahwa ilmu Neuropsikolinguistik mengkaji bagaimana hubungan antara bahasa, berbahasa, dan otak manusia. Sedangkan 
menurut Arifudin (2018: 4) ilmu Neuropsikolingistik menelaah peran otak dalam pemerolehan, produksi, proses pemahaman, gangguan bahasa dan pengetahuan studi interdisipliner tentang kapasitas maupun kemampuan berbahasa dalam otak secara umum.

Kemampuan berbahasa manusia dapat berlangsung melalui proses yang dikendalikan oleh otak penutur. Proses bahasa tersebut, tidak terlepas dengann teorirevolusi otak manusia. Yang mengungkapakan perkembangan bahasa munculnya homoerectus sampai dengan homosapiens yang yang mempunyai jumlah fiber yang berbeda-beda dalam perkembangannya. Fiber tersebut seperti kabel listrik yang memberikan dorongan dalam melakukan sesuatu. Setelah itu, perkembangan terakhir muncul dua hemisfer yang asimitris. Dengan begitu, dapat dilihat bahwa otak manusia mengalami evolusi secara sederhana sampai tahap rumit yang kita miliki saat ini. Seperti yang dikemukakan oleh Laksana, (2015: 18) dahulu pada zaman primitif manusia mengalami kesulitan dalam berkomunikasi sehingga komunikasi tidak memiliki makna. Sekian lama berkembang hingga muncul ide-ide dan terjadilah penyamaan makna-makna dalam berkomunikasi. Sehingga peranan komunikasi dalam kehidupan manusia dapat tersampaikan yakni membagi pengetahuan dan pengalaman.

\section{Senyapan}

Seperti yang peneliti uraikan diawal pembahasan pengujaran secara lancar merupakan pengujaran yang dilakukan dari awal hingga akhir tanpa ada hambatan selama berbicara. Jika ada senyapan dan intonasi yang konstituen yang memungkinkan harus dilakukan atau sesuai dengan jeda yang diberikan. Ujaran yang dilakukan tidak bisa kita buat secara spontan. Begitu juga dalam berbicara tidak semua manusia mampu berbicara secara orisinal dan lancar. Tentu ada senyapan ataupun gangguan dalam berbicara. Senyapan menurut Dardjowidjodjo (2005: 142) adalah satu diantara proses mental saat memproduksi ujaran yang mengalami hambatan. Sedangkan menurut Fraundorf dan Watson (2013) dalam Fida (2019: 3) mendefinisikan senyapan merupakan ketidaklancaran penutur sebagai bentuk gangguan verbal maupun nonverbal yang tidak berhubungan atau menjadi bagian dari pesan yang ingin disampaikan oleh penutur terhadap mitra tutur. Sedangkan Sudaryanto (1993: 250) dalam Pertiwi (2015: 3) berpendapat 
gangguan berbahasa berupa senyapan dimanfaatkan secara mental untuk membedakan unsur yang dilambangkan. Selain itu, merupakan bentuk penundaan awal dalam memerankan fungsi tertentu dalam ujaran. Dengan demikian senyapan merupakan fenomena gangguan penutur dalam berbahasa yang ditandai dengan senyapan saat penutur berujar.

Secara umum, senyapan terjadi hanya selang waktu beberapa detik saja. Yang dominan dipengaruhi oleh perasaan ragu-ragu ataupun hanya kebutuhan untuk bernapas sebentar. Namun berbeda konteks jika ujaran yang sudah terlebih dahulu dihafalkan dan sudah terkonsep sebelumnya. Kebanyaakan manusia melakukan senyapan selama berbicara karena beberapa hal. Pertama, seseorang yang melakukan senyapan sudah terlanjur memulai berbicara tetapi belum siap secara keseluruhan mengenai kata yang akan diproduksi. Kedua, manusia melakukan senyapan dikarenakan lupa dengan apa kata apa yang akan diujarkan. Sehingga, manusia harus mengingat kata apa yang diujarkan. Ketiga, manusia lebih baik dalam memilih kata, diksi yang berkaitan dengan makna kata yang akan diujarkan.

Pemilihan kata tersebut agar meminimalisasi kata yang tidak cocok untuk diujarkan kepada mitra tutur. Namun menurut Dardjowidjojo (2015: 144) ketidaksiapan dan kewaspadaan saat penutur melakukan berbicara terwujud dalam dua macam senyapan: (1) senyapan diam dan (2) senyapan terisi. Pada senyapan diam manusia dalam berbicara berhenti sejenak dan hanya diam. Selanjutnya, menemukan kata yang akan diujarkan manusia melanjutkan ujaran yang sebelumnya terhenti. Sedangkan senyapan berisi ialah senyapan yang dilakukan penutur melalui proses meretrif kata secara tidak cepat. Sehingga diisi dengan senyapan tersebut dengan kata sebagai pengganti. Padanan bahasa yang digunakan yakni kata seperti apa, itu, anu, siapa itu sering dipakai sebagai pengisi saat senyapan terjadi.

\section{Kekeliruan}

Kekeliruan atau kekhilafan dalam berbicara dapat disebabkan karenanya kilir lidah atau penyakit afasia. Kekeliruan ini terjadi dikarenakan dalam memproduksi kata yang diujarkan tidaklah yang dikehendaki. Dalam berujar memproduksi kata yang lain, sehingga memindahkan bunyi atau urutan secara keliru. Berbeda dengan 
kekeliruan yang afasik. Kekeliruan afasia terjadi kaena faktor otak yang terganggu sehingga tidak mampu dalam mengujarkan kata sesuai yang dikehendaki.

a. Kilir Lidah

Kekeliruan dalam berbicara dapat disebabkan oleh kilir lidah dan afasia. Dardjowidjojo (2014: 147) Kilir lidah terjadi saat memproduksi ujaran di mana pembicara terkilir lidahnya sehingga kata yang di produksi bukan kata yang dikehendaki. Sedangkan menurut Jaeger (2005: 2) dalam Mayasari (2015: 2) mengungkapkan kilir lidah adalah suatu kekeliruan penutur dalam perencanaan saat memproduksi ujaran yakni ketika pembicara ingin menuturkan beberapa kata, frasa, atau kalimat dan selama proses perencanaan berlangsung terjadi sesuatu yang keliru sehingga produksinya tidak sesuai dengan perencanaannya.

Sedangkan afasia merupakan penyakit gangguan berbicara yang berkaitan dengan otaknya. Menurut KBBI $\mathrm{V}$ daring penyakit afasia disebabkan kehilangan sebagian ataupun seluruh kemampuan dalam berbicara disebabkan oleh penyakit, cacat, dan cedera pada otak. Ahmadi (2015: 246) kekeliruan gangguan afasia muncul karena otak manusia terganggu sehingga, tidak mampu dalam mengujarkan kata yang diinginkan. Dalam gangguan berbicara berupa kilir lidah mempunyai dua macam jenis. Yakni pertama kilir lidah yang disebabkan karena adanya seleksi kata yang keliru. Yang kedua kilir lidah yang disebakan oleh asembling. b. Kekeliruan Seleksi

Kilir lidah yang di sedangkan seleksi yang keliru terbagi menjadi tiga. Diantaranya: 4) Seleksi semantik

5) Malaproprisme

6) Campur kata(blends)

Gangguan seleksi semantik yang keliru biasa dikenal dengan istilah "Freudian slips" meretrif kata yang tidak diinginkan. Kekeliruan tersebut bukan karena sifatnya yang disengaja. Akan tetapi, mempunyai alasan tertentu. Terkadang disebabkan manusia menyimpan kata-kata berdasarkan sifat kodratinya atau ungkapan lain 
mengenai ciri-ciri kata tersebut. Kekeliruan dalam segi semantik berwujud kata yang penuh dan utuh dari medan semantik yang sama.

Istilah Malaproprisme berasal dari sebuah karangan novel yang bernama Ny. Malaprop. Dalam kisah novel tersebut Ny. Malaprop digambarkan sebagai wanita yang berkelas tinggi dengan memakai kata-kata yang berlebihan. Namun dalam konteks pemakaiannya banyak kekeliruan meskipun sedikit ada kemiripan. Dan kilir lidah tersebut dapat terjadi pada sapa saja. Contoh dalam lawakan banyak sekali pemain-pemain dalam berbicara melakukan kilir lidah yang disengaja. Seperti kata "antisipasi" diganti dengan "antisisapi".

Model yang terakhir kilir lidah disebabkan dengan adanya campur kata (blends) yang terjadi disebabkan manusia sedang dalam keadaan tergesa-gesa sehingga mengambil suku kata atau sebagian suku dari kata pertama atau sebagian kata tersebut. Dalam fenomena campur kata ini banyak terjadi dalam pemakaian bahasa Inggris. Sedangkan dalam bahasa Indonesia sangat jarang terjadi kesalahan campur kata. Hal tersebut disebabkan kata dalam bahasa Indonesia umumnya bersuku kata dua atau lebih. Sehingga dalam pencampurannya tidaklah mudah. Selain itu bahasa Indonesia mempunyai banyak akronim tetapi tidak seluruhnya sengaja diucapkan.

c. Kekeliruan Asembling

Kekeliruan asembling adalah bentuk kekeliruan yang terdapat berupa kata-kata yang dipilih secara benar. Namun, kekeliruan asemblingnya masih terdapat kesalahannya. Salah satu bentuk kekeliruannya dinamakan transposisi. Pada kekeliruan transposisi ini secara spontan penutur memindahkan kata atau bunyi dari posisi ke posisi lainnya. Kesalahan ini terdapat pada kata dan bunyi.

d. Unit-Unit Pada Kilir Lidah

Secara garis besar kita dapat mengetahui tempat yang terdapat unit-unit pada kilir lidah adalah fitur distingtif, segment fonetik, 
sukukata, kata dan konstituen yang lebih besar. Berikut penjelasan mengenai unit-unit kilir lidah:

1) Kekeluruan fitur distingtif

Kekeliruan fitur distingtif merupakan kekeliruan yang terjadi apabila yang terkilir bukan suatu fonem, tapi fitur distingtif dari fonem itu saja. Kekeliruan jenis ini jarang terjadi dalam penuturan. Dalam Bahasa Indonesia dapat dicontohkan pada kata [Pari] yang diujarkan menjadi [Baris].

2) Kekeliruan Segmen Fonetik

Kekeliruan ini terjadi apabila yang terkilir saat berujar yang jumlah fiturnya lebih dari satu. Dan kekeliruan ini terjadi paling umum dikarenakan bunyi yang saling mengganti atau fonem bertukar tempat.

3) Suku Kata

Kekeliruan suku kata banyak ditemukan dalam Bahasa Indonesia.

Contoh: pada kata "Ke-pa-la" saat diujarkan menjadi "Ke-la-pa".

4) Kata

Kekeliruan kata terjadi saat kata yang diinginkan dalam berujar bertertukar tempat dengan kata yang selanjutnya diucapkan. Hal tersebut terjadi karena penutur menukar kata yang seharusnya terucap terlebih dahulu. (www.andimaryam.wordpress.com $)$

b. Afasia

Afasia adalah penyakit gangguan berbahasa di mana penutur tidak dapat berbicara dengan baik karena adanya penyakit di dalam otanya. Penyakit ini umumnya dipengaruhi oleh penutur mengalami stroke yang sebagian otaknya kekurangan oksigen sehingga menjadi cacat. Ada beberapa macam penyakit afasia. Dapat ditentukan daerah hemisfer yang mana yang terkena struke.

Menurut Kalpan (1994) dalam Dardjowidjojo (2014: 214) ada 5 macam penyakit Afasia. Diantaranya: a) Afasia Broca

Seperti namanya penyakit afasia ini menyerang daerah bagian Broca. Daerah Broca berdekatan dengan dengan jalur korteks motorik yang 
bertugas monitoring dalam otak. Dengan begitu alat-alat ujaran, bentuk mulut menjadi terganggu. Seperti ucapannya terpatah-patah, mulut mencong dan ujaran yang diucapkan tidak begitu jelas.

b) Afasia Wernicke

Penyakit afasia jenis ini letak kerusakaannya terdapat pada daerah wernicke yakni bagian yang terletak di belakang dari lobe temporal. Bagian didekatnya juga dapat terkena dampak dari kerusalakan pada alat tersebut. Pada umumnya penderita penyakit ini masih lancar dalam berbicara dalam bentuk sintaksisnya. Namun, kalimat yang diucapkan sering kali tidak sesuai dengan makna ujarannya. Seperti contoh: kata fair menjadi chair.

c) Afasia Anomik

Selanjutnya afasia anomik yang terjadi kerusakan pada bagian depan dari lobe parietal atau pada batas antara lobe parietal dengan temporal. Dalam gangguan berbahasa ini penderita tidak mampu mengakaitan konsep dengan bunyi atau kata yang mewakilinya.

d) Afasia Global

Afasia global merupakan penyakit yang menyerang tidak pada satu bagian saja. Akan tetapi, pada beberapa bagian lainnya. Bahkan kerusakan dapat menyebar pada bagian Broca yang melewati motor sampai menuju Wernicke. Penyakit yang melebar luas dapat berpengaruh secara fisikal dan verbal.

e) Afasia Konduksi

Yang terakhir adalah afasia konduksi yang terjadi kerusakan pada bagian fiber-fiber yang terdapat pada fasikulus arkuat yang menghubungkan dengan lobe frontal dengan lobe temporal. Pada gangguan ini penderita tidak dapat mengualangi kata yang baru saja diberikan.

Namun dia memahami apa yang dikatakan orang lain. Hal tersebut dikarenakan antara kedua lobe tersebut komprehensinya terputus.

\section{Keterkaitan Senyapan Dengan Kilir Lidah}

Keterampilan berbahasa menjadi hal penting dalam berbiacara. Menurut Arsjad dalam (Pangesti: 89) salah satu faktor yang perlu diperhatikan dalam 
kemahiran berbicara adalah ketepatan dalam pengucapan atau pelafalan. Ketepatan dalam pelafalan berupa vokal atau pun konsonan. Jika tidak adanya ketepatan akan terjadi kesalahan dan kekeliruan dalam berbahasa. Kesalahan berbahasa dengan kekeliruan berbahasa sangatlah berbeda. Kesalahan berbahasa merupakan penyimpangann yang bersifat sistematis dan konsisten, sedangkan kekeliruan berbahasa adalah bentuk penyimpangan yang tidak sistematis. Dalam penelitian ini senyapan dan kilir lidah termasuk dalam ranah kekeliruan berbahasa dikarenakan hanya terjadi penyimpangan konstituen pada kata saat memproduksi kalimat.

Seorang penutur saat berkomunikasi, pada dasarnya tidak seluruh ujarannya direncanakan. Jika itu dibayangkan akan banyak waktu yang akan diperlukan seorang penutur untuk mengujarkan suatu tuturan yang terdiri atas banyak kalimat. Sehingga penutur mempunyai tugas ganda yang berpengaruh terhadap munculnya fenomena senyapan dan kilir lidah saat berkomunikasi. Terlebih jika penutur mempunyai pemikiran kata atau kalimat yang masih melayang-layang dalam pikiran. Dengan begitu berpengaruh dalam fenomena tersebut. Hal tersebut sepaham dengan Nababan (1992) dalam Fida (2019: 13) yang mengulas bahwa senyapan dapat memcerminkan adanya syarat beban (overloading) atau keterlambatan yang dialami oleh penutur saat berbicara. Terlebih jika penutur belum mengerti sepenuhnya dengan konsep yang akan diujarkan. Keterlambatan yang dialami menimbulkan peningkatan jumlah ketidaklancaran dalam tuturan. Oleh karena itu, terdapat keterkaitan antara senyapan dan kilir lidah. Dengan memperhatikan pengujaran penutur saat berbicara satu kalimat demi kalimat.

Dalam satu kalimat saat berujar bisa saja penutur melakukan senyapan dan juga kilir lidah. Perhatikan peta konsep berikut: 


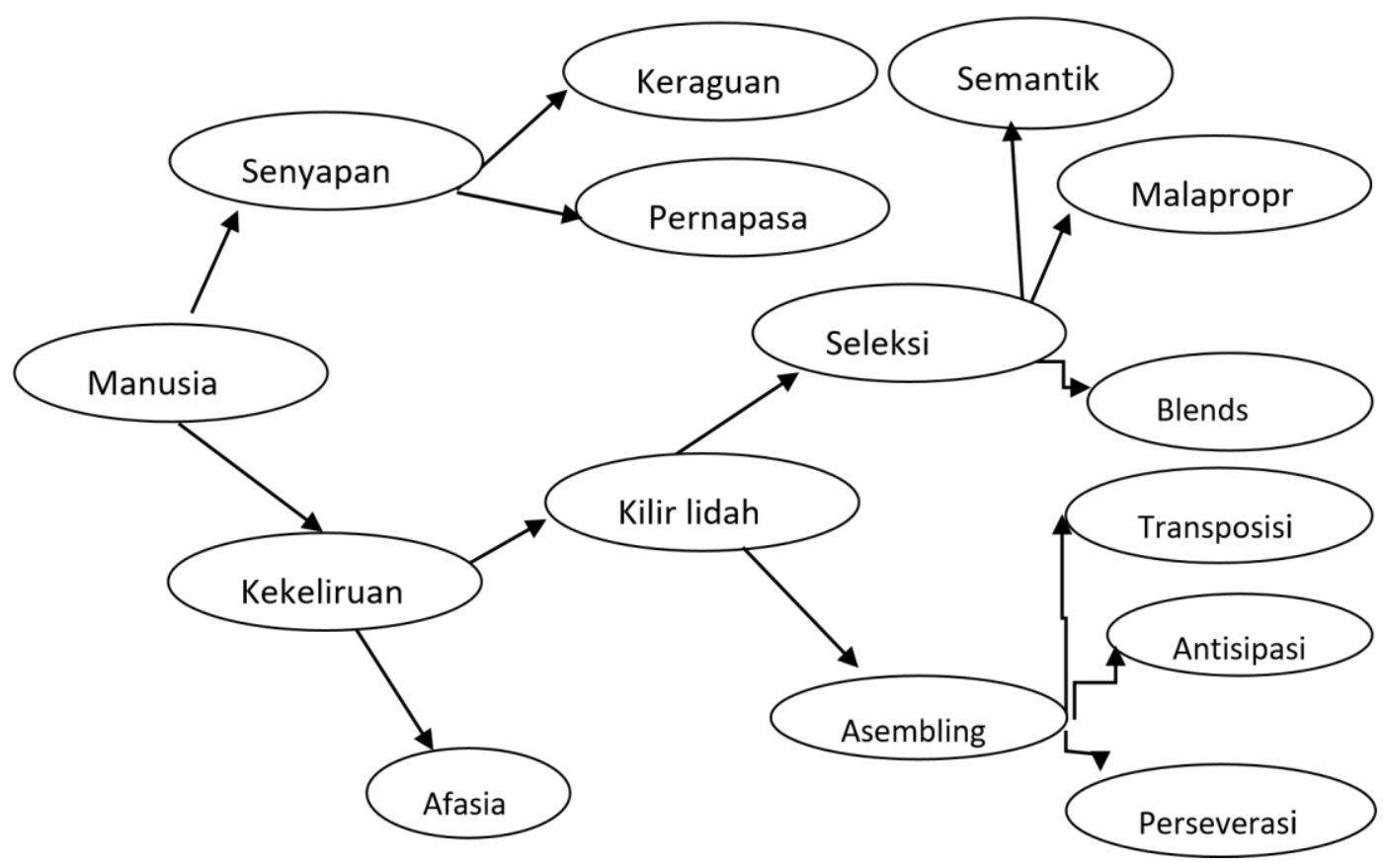

Gambar 2.2 : Kekeliruan Sebagai Bukti Ujaran

(Sumber Gambar: Buku Psikolinguistik Pemahaman Bahasa Manusia)

\section{Metode Penelitian}

Dalam penelitian ini,jenis penelitian yang digunakan adalah penelitian kualitatif deskriptif. Dengan objek dalam penelitian ini peneliti mengambil objek di acara Gelar wicara Mata Najwa 2020 pada bulan Mei sampai dengan bulan Juni dengan tema: Otak Atik Mudik, Cerita Pahlawan Kesehatan Hati-Hati Relaksasi, Idulfitri saat Pandemi dan Belajar dari Pandemi yang tayang di statsuin TV TRANS 7. Sedangkan pengumpulan data menggunakan teknik simak libat cakap, simak bebas lipat cakap, catat dan rekam (Mahsun, 2014 : 92).

Dalam penelitian ini peneliti menggunakan analisis data kualitatif model Straus dan Corbin (Grounded Theory). Menurut Straus dan Corbin (1990) dalam Emzir, (2010: 137) terdapat tiga tahap analisis data Grounded Theory, diantaranya: (1) pengkodean terbuka (Open Coding), (2) pengkodean berporos (Axial Coding) (3) pengkodean selektiv (Selektive Coding). Dalam analisin Grounded Theory menekankan bahwa garis besar dalam analisis ini andalah artifisial. Yang berarti perbedaan jenis ketiga pengkodean peneliti dapat melakukan secara keseluruhan atau hanya tunggal saja. Namun dalam penelitian ini peneliti menggunakan pengkodean berporos dengan model paradigma. 


\section{Hasil dan Pembahasan}

Hasil dari penelitian terdapat kesalahan berbicara berupa senyapan dan kilir lidah yang dilakukan oleh narasumber dan moderator. Najwa Shihab sebagai moderator acapkali melakukan senyapan pada awal kalimat. Berbeda dengan kilir lidah, hanya ditemukan beberapa saja. Secara umum, manusia berbicara sambil berpikir sehingga semakin sulit topik pembicaaraan maka semakin banyak jumlah senyapan yang akan terjadi.

Berikut merupakan contoh kutipan percakapan yang terdapat kesalahan berbicara berupan senyapan dan kilir lidah.

\section{A. Seksi pertama Utak Utik Mudik}

\section{Utak Atik Mudik Seksi 1(Tidak Ada Pilihan Lain Selain Mudik)}

Pada seksi pertama dengan tema Utak atik mudik Seksi 1 menjelaskan tentang beberapa masyarakat yang terkena dampak dari pandemi COVID 19. Diantaranya adalah Yulia, Hisyam dan Hafid. Ketiga orang tersebut merupakan orang perantauan yang berkerja di ibu kota Jakarta yang dilema untuk mudik namun kesulitan untuk bertahan hidup di ibu kota.

$$
\begin{array}{cl}
\text { Moderator } & \text { :Najwa Shihab } \\
\text { Narasumber } & \text { : } \\
\text { a. Nama } & \text { : Yulia Mukti Trianingsih } \\
\text { Alamat } & \text { : Jombang Jawa Timur } \\
\text { Pekerjaan } & \text { : Pegawai kantin pada salah satu pabrik di Sidoarjo } \\
\text { b. Nama } & \text { : Hisyam Masruri } \\
\text { Alamat } & \text { : Tegal Jawa Tegah } \\
\text { Pekerjaan } & \text { : Pengemudi Ojek Online } \\
\text { c. Nama } & \text { : Hafid Priawitantoro } \\
\text { Alamat } & \text { : Semarang Jawa Tengah } \\
\text { Pekerjaan } & \text { : Guru }
\end{array}
$$

Pada video Seksi 1 terjadi senyapan dan kilir lidah yang dilakukan oleh Hafid yang bekerja sebagai guru salah satu intansi di Jakarta. Berikut merupakan percakapan yang terdapat senyapan dan kilir lidah. Percakapan dengan narasumber pertama

Najwa shihab: " Baik, mbak Lia suaranya masih kurang jelas. Saya akanminta [ee] bagian teknis untuk memperbaiki suara mbak Lia. Sambil saya mencoba menyapa pak Hisyam dulu”. 


\section{Percakapan dengan narasumber kedua}

Najwa shihab: "Ada ongkos untuk pulang pak"

Hiyam : "[Ee] alhamdulillah sudah ada"

\section{Percakapan dengan narasumber ketiga}

Hafid : " Sebenarnya kalau saya secara pribadi ingin menaati pemerintah ya, itu dalam arti kalaupun tidak mudik tidak masalah. cuma permasalahannya dari sisi penghasilan. Seharusnya sudah berkerja akhirnya penghasilannya kan juga ditunda. Akhirnya penghasilannya juga ditunda tadinya mau mikir untuk mudik, cuma mudik pun dilarang sampai akhirnya kemaren ada larangan kalo gak salah tanggal 24 April itu dilarang dan akhirnya tetap tidak mudik. Karena kalaupun mudik ada khawatir kan nyebar virus. Karena [perantau] [ee] oh soryy [pemudik] sendiri kan mendapat lebel pembawa virus nih. Jadi agak dilema sih.

Najwa Sihab : “[E] pak Hafid tinggal dimana sekarang pak?” Hafid :

"Sekarang di Kemayoran Jakarta pusat".

Najwa Sihab : “[Ee] ngekos?”.

Hafid : "Iya di kos daerah Kemayoran".

Najwa Sihab : “[Ee] jadi-jadi ngekos ya pak. Rencana kalau mudik itu di kota apa pak".

Kesalahan berbicara berupa senyapan dan kilir lidah dalam video acara Gelar Wicara Mata Najwa 2020. Data yang diperoleh berdasarkan pengamatan peneliti di dalam video acara Gelar Wicara Mata Najwa. Faktor-faktor yang memengaruhi kesalahan berbahasa diantaranya:

a. Ketidaksiapan penutur dalam memproduksi kalimat

Tidak semua penutur siap dalam berbicara. Munculnya senyapan dan kilir lidah salah satunya karena penutur tidak siap dalam memproduksi kalimat. Selain itu, faktornya adalah penutur tergesa-gesa dalam berbicara. b. Kebiasaan

Faktor selanjutnya adalah kebiasaan penutur dalam melakukan senyapan.

Faktor kebiasaan ini terjadi pada kekeliruan berbicara berupa senyapan saja. Kebiasaan tersebut sulit dihindari oleh penutur. Hampir setiap kalimat yang diujarkan terdapat senyapan berupa kata [ee] baik bertempat pada batas konstituen yang lain ataupun sebelum kata pertama konstituen. 
c. Kesamaan dalam suku kata yang diujarkan

Kilir lidah dapat dipengaruhi oleh faktor kesamaan dalam suku kata baik di awal maupun akhir. Kesamaan suku kata antara kata yang ingin diucapkan tertukar dengan kata yang tidak ingin diucapkan. Berikut merupakan data-data yang ditemukan oleh peneliti mengenai senyapan dan kilir lidah yang dilakukan oleh Najwa Shihab sebagai moderator dan narasumber. (https://www.youtube.com/c/Najwashihab/videos)

A. Video pertama Utak Utik Mudik a. Utak Atik Mudik Seksi 1 (Tidak Ada Pilihan Lain Selain Mudik

\section{Najwa Shihab (moderator)}

Pada video pertama dengan tema Utak Utik Mudik (Tidak Ada Pilihan Lain Selain Mudik) Najwa Shihab melakukan senyapan berupa kata [e] sebanyak 6 kali. Senyapan yang dilakukan oleh Najwa Shihab merupakan senyapan berisi. Letak senyapan yang dilakukan oleh Najwa Shihab yaitu pada batas konstituen yang lain dengan jumlah 3 senyapan. Selain bertempat pada konstituen lainnya senyapan yang dilakukan oleh Najwa Shihab juga bertempat pada sebelum kata pertama dalam konstituen dengan jumlah 3 kata. Berikut merupakan ungkapan yang menunjukkan senyapan yang dilakukan oleh Najwa Shihab

"Saya akan minta [ee] bagian teknis untuk memperbaiki suara mbak Lia" "Oke saya ingin tau lebih jauh nanti kondisi seperti apa yang membuat pak [e] Hafid, yang membuat pak Hisyam mbak Yulia [e] tidak ada pilihan lain selain harus pulang ke rumah" “[E] pak Hafid tinggal dimana sekarang pak?”

\section{“[Ee] ngekos?" “[Ee] jadi-jadi ngekos ya pak"}

\section{Hisyam (narasumber kedua)}

Senyapan juga dilakukan oleh narasumber kedua sejumlah 1 senyapan dalam kategori senyapan berisi. Senyapan berisi yang dilakukan oleh narasumber kedua berada ditempat sebelum kata pertama dalam konstituen. Berikut merupakan senyapan oleh Hisyam.

“[Ee] alhamdulillah sudah ada” 


\section{Hafid (narasumber ketiga)}

Hafid sebagai narasumber ketiga telah melakukan senyapan dan kilir lidah. Senyapan tersebut dilakukan sebanyak 4 kali. Senyapan tersebut bertempat pada batas konstituen yang lain senyapan yang dilakukan oleh narasumber ketiga adalah senyapan berisi dengan kata [ee]. Berikut merupakan senyapan yang dilakukan oleh Hafid.

"Ke Semarang, [ee] nah jadi [e] kalo misalnya pengen mudik ya. [ee] Cuma kan sekali lagi kan dari pemerintah kalaupun mudik ada peraturan harus isolasi selama 14 hari”

Selain melakukan senyapan berisi, narasumber 3 juga melakukan kilir lidah sebanyak 1 kali. Kilir lidah yang dilakukan oleh narasumber 3 berupa kata [perantau]. Secara faktual narasumber 3 ingin mengucapkan kata [pemudik]. Namun, yang terujar adalah kata [perantau]. Kilir lidah yang dilakukan narasumber 3 termasuk kategori seleksi kata yang keliru dalam bidang semantik. Berikut merupakan kilir lidah yang dilakukan oleh Hafid.

“Karena [perantau] [ee] oh soryy [pemudik] sendiri kan mendapat lebel pembawa virus nih"

Berdasarkan uraian di atas dalam video pertama terjadi senyapan sebanyak 9 kali berupa senyapan berisi yang bertempat pada batas konstituen dan sebelum kata pertama pada konstituen. Dan sebanyak 1 kali kilir lidah pada seleksi kata yang keliru dalam bidang semantik.

\section{E. Kesimpulan}

Kekeliruan berbicara salah satunya adalah senyapan dan kilir lidah. Senyapan merupakan proses mental yang mengalami hambatan saat berbicara. Sedangkan kilir lidah merupakan kekeliruan yang disebabkan karena penutur terkilir saat berujar sehingga apa yang diucapkan tidak sesuai dengan kata yang diinginkan. Seperti pada acara Gelar Wicara Mata Najwa 2020. Kemahiran berbicara dilakukan secara spontanitas dalam merespon pertanyaan. Sehingga banyak sekali senyapan dan kilir lidah yang terjadi. Baik yang dilakukan oleh penutur atau pun mitra tutur. 
Senyapan dan kilir lidah dalam acara Gelar Wicara Mata Najwa 2020 diantaranya berupa senyapan berisi yang lebih dominan terbanyak. Penutur hanya beberapa kali saja melakukan senyapan diam yang terletak dari berbagai tempat. Diantaranya: batas jeda gramatikal, sebelum kata pertama dan pada batas konstituen lainnya. Wujud dari senyapan diantaranya [e], [apa], [a], [ab], [se..], dan [apa ya]. Sedangkan kilir lidah hanya dilakukan beberapa kali. Contohnya kata [perantau] menjadi [pemudik]. Dengan begitu, dalam berbicara penutur lebih sering melakukan senyapan dari pada kilir lidah.

Namun jika penutur sudah menyiapkan mengenai konsep berbicara, penutur mampu meminimalisasinya. Faktor lain terjadinya senyapan dan kilir lidah dapat dipengaruhi oleh penutur yang tidak siap. Dengan begitu, penutur tidak dapat memproduksi kalimat dengan baik. Hal itu, dapat terjadi karena mitra tutur merespon pertanyaan penutur secara spontanitas. Selanjutnya, adanya faktor penutur tergesa-gesa dalam berbicara. Sehingga apa yang diujarkan acap kali terkilir ataupun belum dapat memproduksi dengan baik dengan memunculkan senyapan. Selain itu, ada juga dipengaruhi oleh kebiasaan senyapan sehingga setiap kalimat yang diucapkan mengalami senyapan. Sedangkan kilir lidah sering kali dipengaruhi oleh adanya kesamaan antara suku kata yang diucapkan dengan kata yang diinginkan. Hal tersebut seringkali terjadi pada saat penutur berbicara.

\section{Daftar Rujukan}

Afifudin. 2018. Neuropsikolinguistik. Jakarta: PT RAJAGRAFINDO PERSADA.

Ahmdi, Anas \& Jauhar, Muhammad. 2015. Dasar-Dasar Psikolinguistik. Jakarta: Prestasi Pustakaraya.

Chaer, Abdul. 2013. Psikolinguitik: Kajian Teoritis. Jakarta: PT RINEKA CIPTA.

Dardjowidjojo, Soejono. 2014. Psikolinguistik: Pengantar Pemahaman Bahasa Manusia. Jakarta: Yayasan Pustaka Obor Indonesia.

Mahsun. 2014. Metode Penelitian Bahasa. Jakarta: PT RAJAGRAFINDO PERSADA.

Mayasari, Ira. 2015. Senyapan dan Kilir Lidah dalam Produksi Ujaran (Kajian Psikolinguistik) dari Fakultas Bahasa dan Seni Universitas Indraprasta 
PGRI Jakarta, Jurnal Bahasa Indonesia, (Online), Jilid 1,No. 1, (http://jounal.lppmunindra.ac.id).

Muleong. 2011. Metode Penelitian Kualitatif. Bandung: PT REMAJA ROSDAKARYA.

Pangesti, Fida. Senyapan Dan Kilir Lidah Berdampingan dalam Produksi Ujaran dari Universitas Muhammadiyah Malang,Jurnal Bahasa Indonesia, (Online), Jilid 1, No 1, (https://hastatawiyata.ub.ac.id). 